\title{
Developing 3Dmetric Media Prototype through a Hypothetical Learning Trajector to Train Students Spatial Skill
}

\author{
1*Mohammad Faizal Amir, Elementary School Teacher Education Department, Universitas Muhammadiyah Sidoarjo, Sidoarjo, \\ Indonesia \\ ${ }^{2}$ Niko Fediyanto, Management Department, Universitas Muhammadiyah Sidoarjo, Sidoarjo, Indonesia \\ ${ }^{3}$ Chusnul Chotimah, Elementary School Teacher Education Department, Universitas Muhammadiyah Sidoarjo, Sidoarjo, \\ Indonesia \\ ${ }^{4}$ H E Rudiyanto, Elementary School Teacher Education Department, Universitas PGRI Madiun, Madiun, Indonesia
}

\begin{abstract}
Currently, the transformation industry 4.0 was going thoroughly, so that education must also transform to prepare students reaching standards technology industry. Augmented Reality (AR) is one of the major technological revolution. The purpose of this research is to develop a media-based 3Dmetric AR through Hypothetical Learning Trajectory, making students more easily develop their spatial abilities. The research method used is Design research in instructional materials development theorist based problems. The results of this research are the prototype of the 3Dmetric media through HLT right used to develop the ability of students in the spatial dimensions of rotation, constructive space, reconstruction, visualization, and orientation. By using the media 3Dmetric, students can perform spatial geometry activity hypothesis 6. 3DMetric media through HLT is a constructivist and meets AR design principles, i.e. giving challenge, give fantasy, and look at the part that is not visible to the user.
\end{abstract}

Keywords--- Augmented Reality, 3D Metric, Instructional Media

\section{Introduction}

The term "industry 4.0" is often associated with the concept of the Internet of Things (IoT), which refers to the device's network which have abilibertukar data [1]. Education must also transform to prepare students reaching standards of technology industry 4.0 [2]. Augmented Reality (AR), which is one of the major technology revolution [3] in education, helping teachers implement teaching approach [4], so it's a learning experience, learning, performance and motivation of students be better [5], [6].

AR technologies can be relied upon creates learning media [7], in the form of a mobile device that gives a virtual information with real dimensions [8]. The use of media-based learning, AR to students to train the ability of virtual spatial problems in geometry students [9]-[11].

Hypothetical Learning Trajectory (HLT) is a part of the design research that connects theory and teaching experiment instructional in the real condition. HLT contains alternative activities and performance of students during the study [13]. Thus, it is a development of prototype instructional media AR based HLT that is used to train students spatial ability. AR Media developed a prototype named the Media 3Dmetric (3 dimensional and Geometric).

\section{Experimental Method}

This research was done by using Design Research model by Gravemeijer. The steps of Design Research consist of a preliminary design, teaching experiment, and retrospective analysis [14]. Preliminary design phase includes a review of the literature and the development of HLT

\section{Result and Discussion}

A. Creating HLT (Hypothetical Learning Trajectory)

The 3Dmetric development is done through the development of HLT (Hypothetical Learning Trajectory), based on the student's spatial dimension indicator rotation, constructive space, reconstruction, visualization, and orientation [15], [16]. Complete dimensions, indicators, activities, and hypothesis are described in Table 3.1. At

*Corresponding Author: Mohammad Faizal Amir, Universitas Muhammadiyah Sidoarjo, email: faizal.amir@umsida.ac.id Article History: Received: 15 Apr. 2018 Revised: 1 May 2018 Accepted: 20 May 2018 
least, this is done to make the learning process become correctly directed and effective. sHLT includes activity and learning hypothesis based on the indicators [17].

Table 1. Dimension dimension, Indicator, Activity, and Hypothesis of Students' Spatial Ability

\begin{tabular}{|l|l|l|l|}
\hline Dimension & \multicolumn{1}{|c|}{ Indicator } & \multicolumn{1}{|c|}{ Student Activity } & \multicolumn{1}{c|}{ Hypotheses } \\
\hline Rotation & $\begin{array}{l}\text { investigating } \\
\text { geometric sphere }\end{array}$ & $\begin{array}{l}\text { Activity 1 } \\
\text { Students recognize the image of } \\
\text { geometrical sphere being rotated } \\
\text { rotated }\end{array}$ & $\begin{array}{l}\text { Hypothesis 1 } \\
\text { students can draw a geometrical } \\
\text { sphere rotated once }\end{array}$ \\
\hline $\begin{array}{l}\text { Constructive } \\
\text { Space }\end{array}$ & $\begin{array}{l}\text { state inter-geometrical } \\
\text { sphere positions }\end{array}$ & $\begin{array}{l}\text { Activity 2 } \\
\text { students connect the visual parts } \\
\text { of the geometrical sphere }\end{array}$ & $\begin{array}{l}\text { Hypothesis 2 } \\
\text { students can determine at least } \\
\text { one substance of geometrical } \\
\text { sphere }\end{array}$ \\
\hline Reconstruction & $\begin{array}{l}\text { Constructing and } \\
\text { representing geometry } \\
\text { models illustrated on } \\
\text { flat areas in the } \\
\text { context of space }\end{array}$ & $\begin{array}{l}\text { Activity 3 } \\
\text { students draw things surround } \\
\text { them by representing } \\
\text { geometrical objects }\end{array}$ & $\begin{array}{l}\text { Hypothesis 3 } \\
\text { Students can draw 4-5 things } \\
\text { surround them precisely }\end{array}$ \\
\hline Visualization & $\begin{array}{l}\text { Indentify and classify } \\
\text { geometrical sphere }\end{array}$ & $\begin{array}{l}\text { Activity 4 } \\
\text { a. students visualize geometrical } \\
\text { sphere into nets } \\
\text { b. students visualize nets into } \\
\text { geometrical sphere }\end{array}$ & $\begin{array}{l}\text { Hypothesis 4 } \\
\text { a. Students can visualize } \\
\text { geometric spheres into a nets } \\
\text { sphere with a simple side. } \\
\text { b. For the more complex sides, } \\
\text { the students have difficulty in } \\
\text { determining faces in the nets } \\
\text { sphere or geometric sphere }\end{array}$ \\
\hline Orientation & $\begin{array}{l}\text { Imagining forms or } \\
\text { position of a } \\
\text { geometrical object } \\
\text { viewed from a certain }\end{array}$ & $\begin{array}{l}\text { Activity 5 } \\
\text { Students predict geometrical } \\
\text { sphere viewed from other } \\
\text { prespectives }\end{array}$ & $\begin{array}{l}\text { Hypothesis 5 } \\
\text { Students understand front view, } \\
\text { side view and top view of } \\
\text { geometrical sphere }\end{array}$ \\
\hline
\end{tabular}

\section{B. 3Dmetric Media Design}

3Dmetric was developed using Blender version 2.79, tracker and Augment application to read the coding of Blender model [18]. Figure 1 shows the preface the Blender to make it easier in the process tracker AR or target image. Through the Blender, we can easily choose to wake up space as needed. Figure 2 shows the making of the object through a Blender. Create a tracker as a means of detection of Augmented reality, thus unreadable by the Augment to display 3D results has been done on Blender engine, the tracker can be seen in Figure 3.

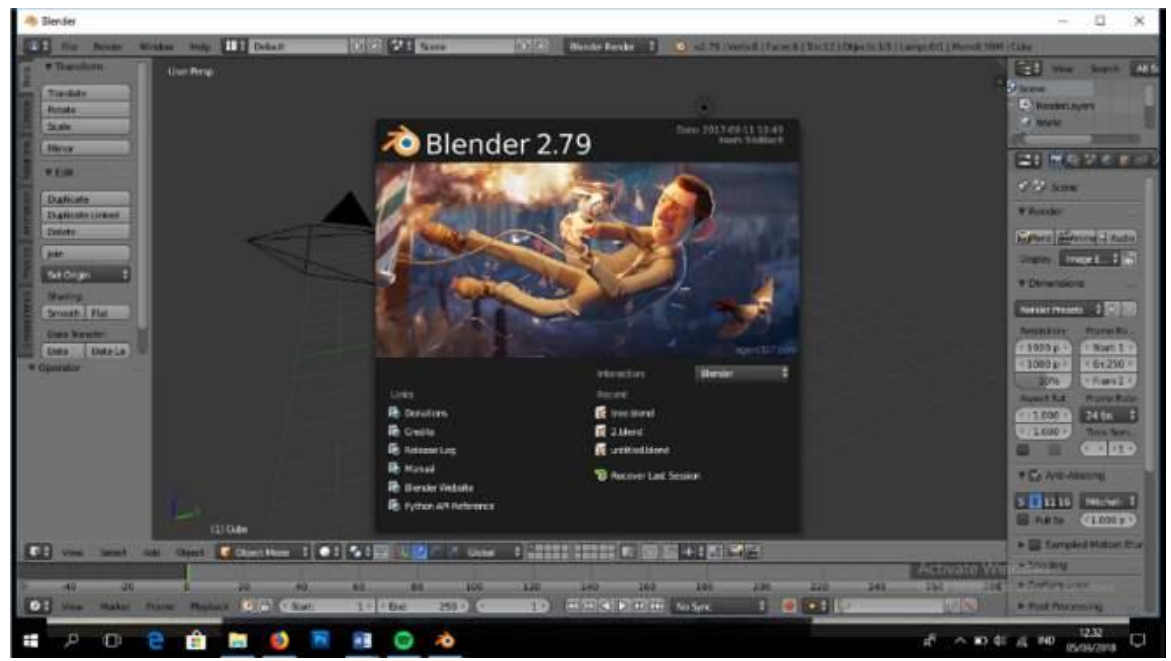

Figure 1. Preface Blender 


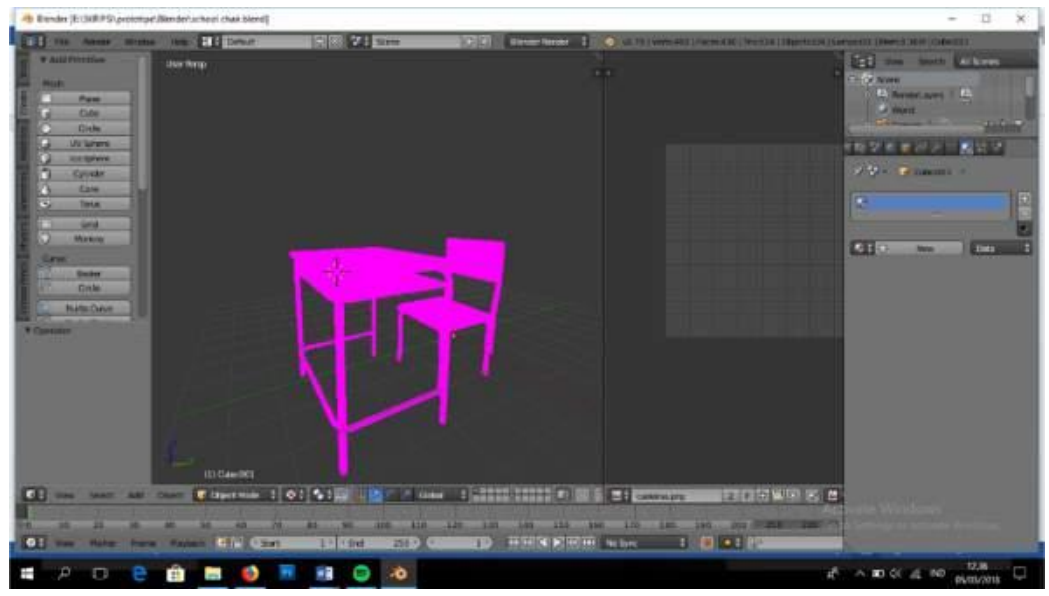

Figure 2. The 3Dmetric object making, using Blender

The next stage was inputting the 3Dmetric continued object with the tracker has been created on the website of Augment, as shown in Figure 4 and Figure 5. The model should certainly be in the mode which everyone can access the model without being logged in to an account. Once the process is complete, the inputting 3Dmetric media can be operated with open-source Applications on Smartphones, Augmented by camera in smartphone to scan the tracker that have been printed before. The results of the deployment of Augmented Reality can be seen in Figure 6, it can be seen that the objects (chairs and tables) can "emerge" from the monitor screen.

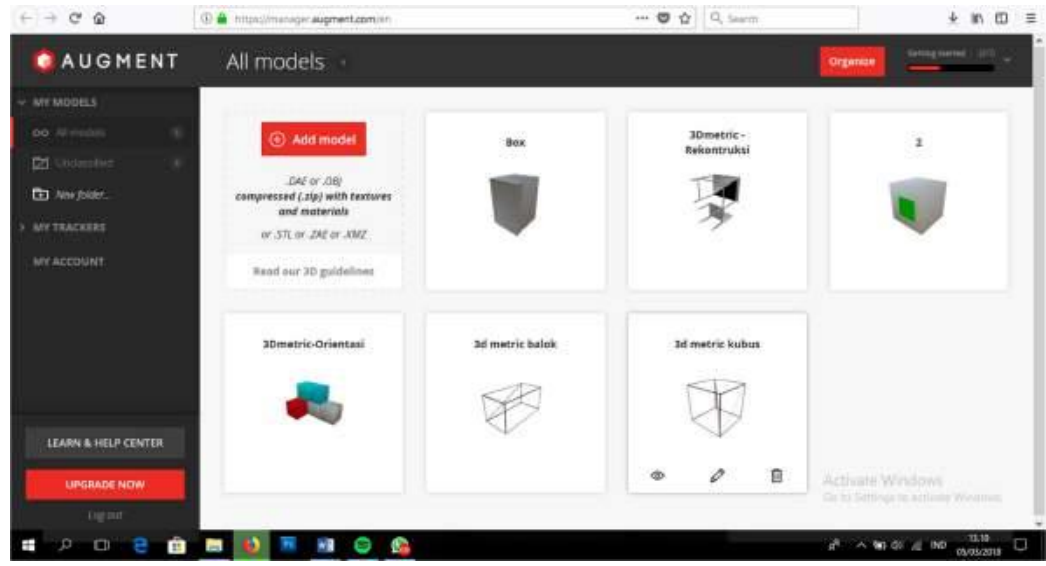

Figure 4. Augmented Website to input 3D model

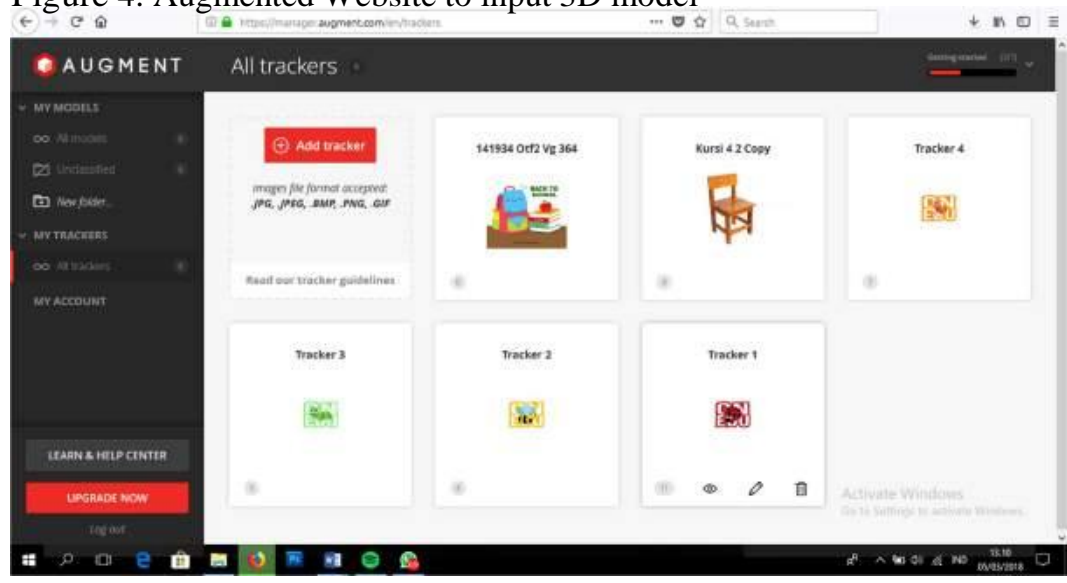

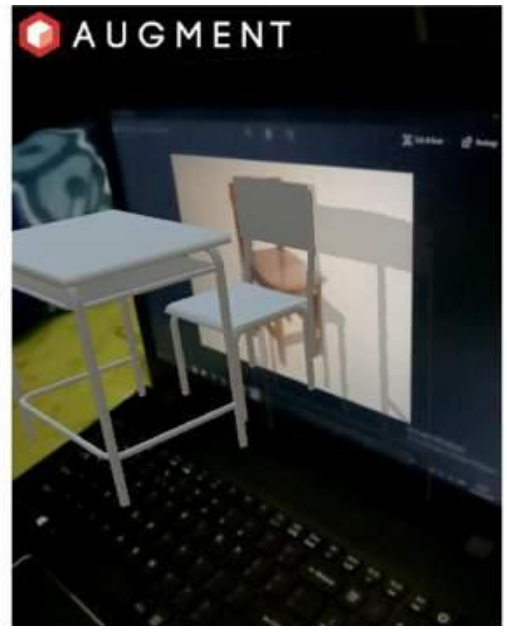

Figure 6. Interface object chair

Figure 5. Augment Website to input tracker

\section{Prototype Usage}

The research result described below includes the end user interface design with the use of the prototype along with a discussion of how it works through the HLT. To open models of media 3dmetric, the first step to do is to install the application on the playstore augment. Figure 7 shows the layout application augment. After installing the 
application and open it, click the scan button to process AR tracker so that it turns into a media object 3Dmetric. Figure 8 shows a hypothesis of activity 1 3Dmetric media, which makes the students are able to distort an object or an object that is on him without spending a lot of energy so that they are easier to understand a part of geometric objects. In addition, this enables students to draw back an object that has a geometry sphere surround them easier.

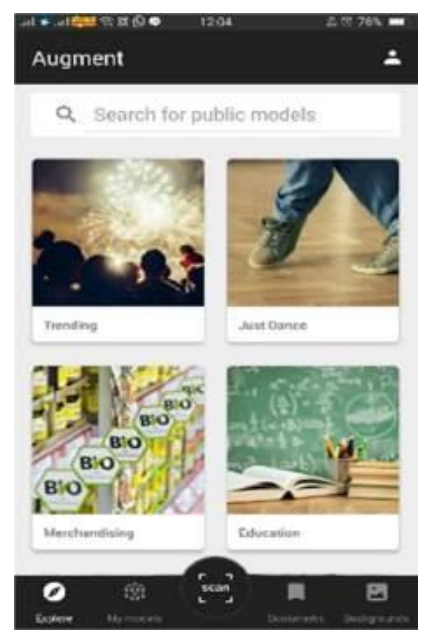

Figure 7. The Initial Display of augment application

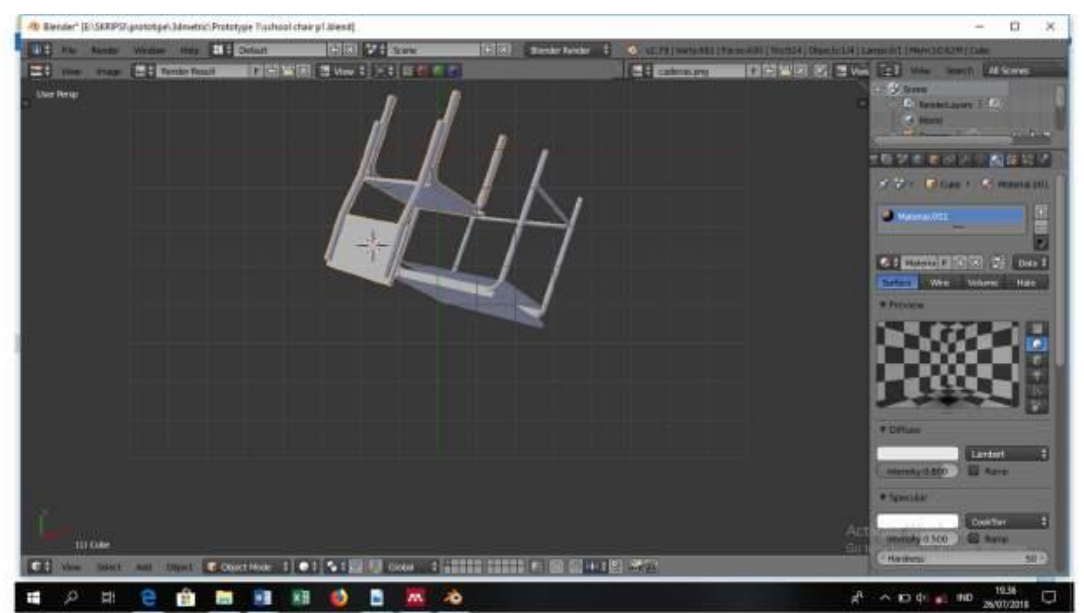

Figure 8. Hypothesis of acivity 1 Media 3Dmetric

Figure 9 shows a hypothetical Activity 2 medium 3Dmetric, where students may mention the elements of geometric spheres particularly cube. The elements of geometric spheres include edges, faces, and diagonal. Activity 2 facilitate students to understand the items on geometric sphere, so the student can state the position between the elements of the sphere. Figure 10 shows the hypothesis of activity 3 media 3Dmetric which can make students to clearly see the diagonal about space and the diagonal side and ease the students in both distinguishing and calculating the diagonal spaces and diagonal faces. Figure 11 shows the hypothesis of Activity 4 media 3Dmetric which make students to know how to make a net through geometric sphere that can be rotated so that it the faces of the geometric sphere and able to make nets from geometric sphere that has patterned faces with indicators that identify and classify image geometry, as well as investigating the geometry of an object. Figure 12 shows a hypothesis of Activity 5 media 3Dmetric where students can play the sphere so they can see from different angles. Students can imagine the sphere or position of an object's geometry seen from a certain point of view.

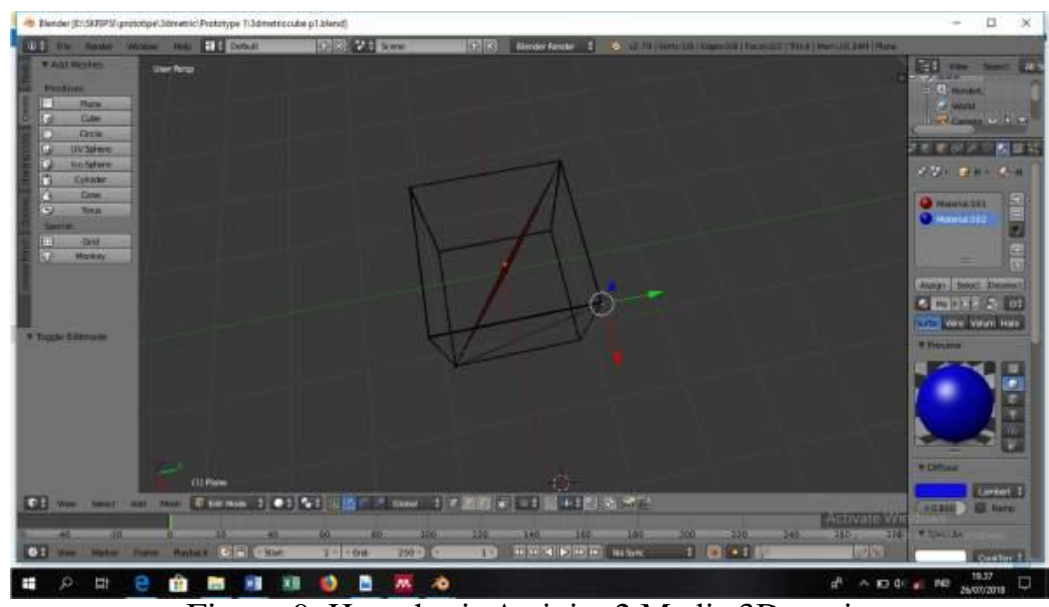

Figure 9. Hypothesis Activity 2 Media 3Dmetric 


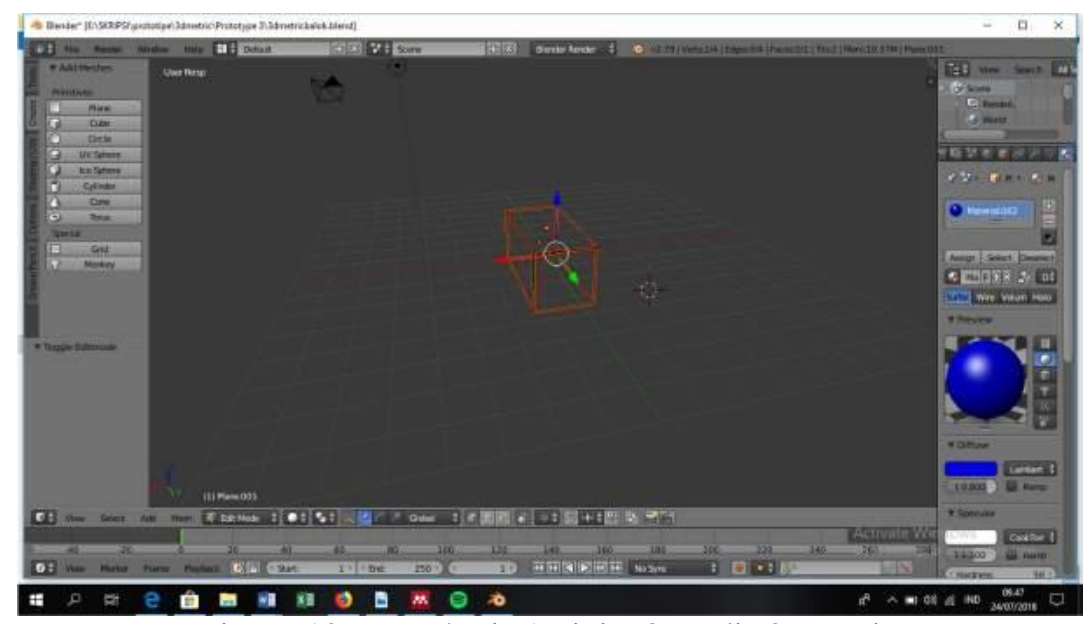

Figure 10. Hypothesis Activity 3 Media 3Dmetric
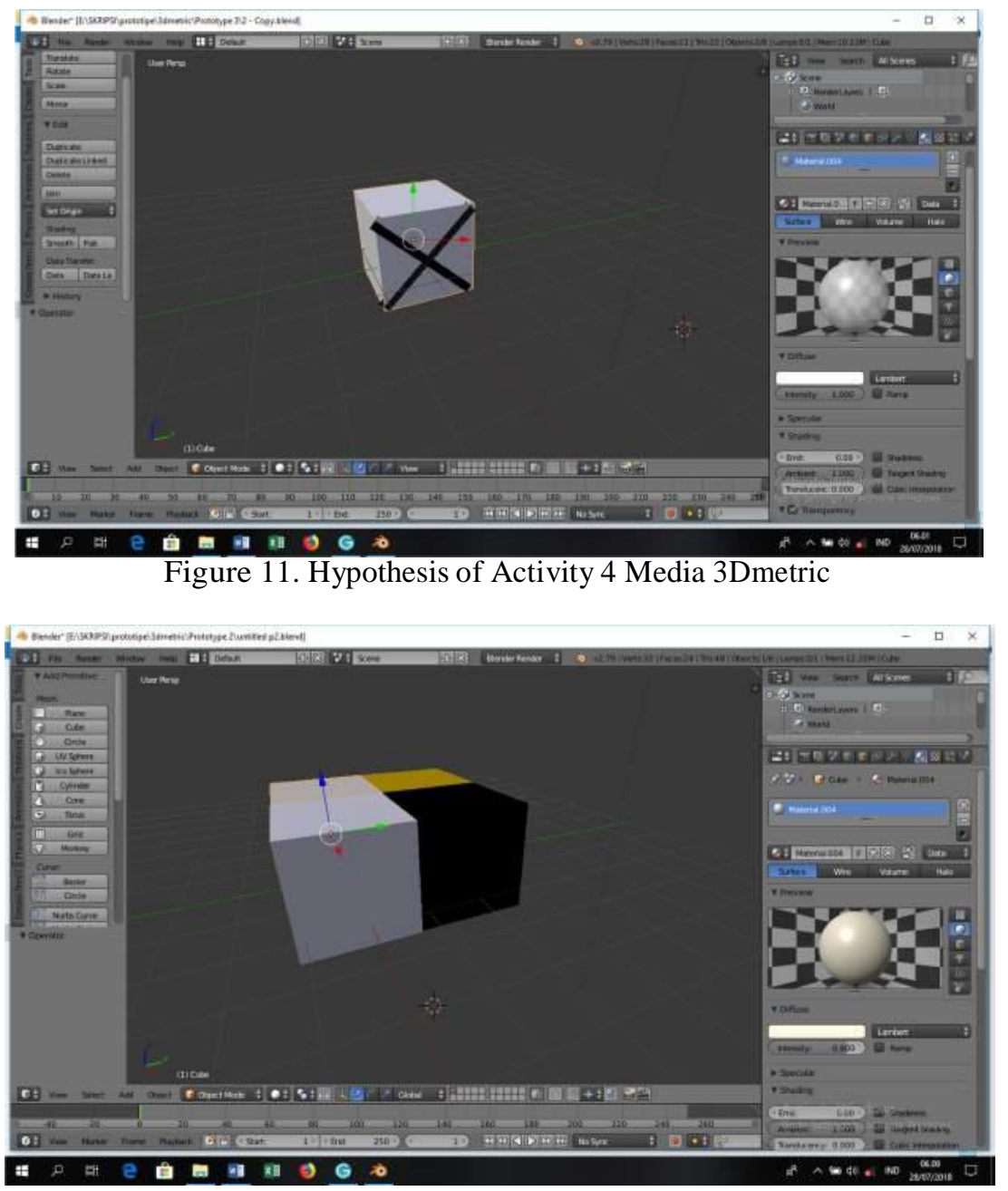

Figure 12. Hypothesis of Activity 5 Media 3Dmetric

The development of prototype media 3DMetric via the HLT has three principles, i.e. giving the challenge, fantasy, and looking at the invisible part for the user [19]. Technology-based media, including 3DMetric AR made $2 \mathrm{D}$ object looks like 3D. The positive consequences of the AR usage are real world contextual visualization, annotation, and vision-haptic visualization [20]. In line with the theory of constructivist learning, facilitating students learn real-world, physical and 3DMetric media also facilitate metacognition awareness, authentic inquiry, observation, guiding, and teaching feedback [21]. 


\section{Conclusion}

The 3Dmetric media via HLT Prototype is appropriate to use in developing the ability of students in the spatial dimension of the rotation, the constructive sphere, reconstruction, visualization, and orientation. By using the media 3Dmetric, students can do the 6 hypotheses of Activity concerning geometric sphere. 3DMetric media through constructivist oriented HLT and meets AR design principles, i.e. giving challenge, fantasy, and look at the invisible part for the user.

\section{References}

[1] F. D. Pace, F. Manuri, and and A. Sanna, "Augmented Reality in Industry 4 . 0," Am. J. Comput. Sci. Inf. Technol, vol. 6, no. 1, pp. 1-7.

[2] M. Rüßmann et al., "Industry 4.0. The Future of Productivity and Growth in Manufacturing," Bost. Consult., no. April, pp. 1-5, 2015.

[3] K. Lee, “Augmented Reality in Education and Training,” Link. Res. Pract. to Improv. Learn., vol. 56, no. 2, pp. 13-21, 2012.

[4] M. Akçayır and G. Akçayır, "Advantages and challenges associated with augmented reality for education: A systematic review of the literature," Educ. Res. Rev., vol. 20, no. 1, pp. 1-11, 2017.

[5] Hsin-KaiWu, S. Wen-YuLee, H.-Y. Chang, and J.-C. Liang, "Current status, opportunities and challenges of augmented reality in education," Comput. Educ., vol. 62, no. March, pp. 41-49, 2013.

[6] C.-M. Chen and Y.-N. Tsai, "Interactive augmented reality system for enhancing library instruction in elementary schools," Comput. Educ., vol. 59, no. 2, pp. 638-652, 2012.

[7] P. M. O'Shea, “Augmented Reality in Education: Current Trends,” Int. J. Gaming Comput. Simulations, vol. 3, no. 1, 2011.

[8] K.-H. Cheng, "Surveying Students ' Conceptions of Learning Science by Augmented Reality and their Scientific Epistemic Beliefs,” EURASIA J. Math. Sci. Technol. Educ., vol. 14, no. 4, pp. 1147-1159, 2018.

[9] H. Kaufmann, K. Steinbügl, A. Dünser, and J. Glück, "General Training of Spatial Abilities by Geometry Education in Augmented Reality," in Annual Review of CyberTherapy and Telemedicine, 2005, pp. 65-76.

[10] R. Raskar, G. Welch, and H. Fuchs, "Spatially Augmented Reality," Methods, no. 919, pp. 1-7, 1998.

[11] R. Raskar and K.-L. Low, "AFRIGRAPH '01 Proceedings of the 1st international conference on Computer graphics, virtual reality and visualisation," in Interacting with spatially augmented reality, 2001, pp. $101-108$.

[13] P. Cobb, J. Confrey, A. diSessa, R. Lehrer, and L. Schauble, "Design Experiments in Educational Research," Educ. Res., vol. 32, no. 1, 2003.

[14] K. Gravemeijer and D. van Eerde, "Design Research as a Means for Building a Konwledge Base for Teachers and Teaching in Mathematics Education,” Elem. Sch. J., vol. 109, no. 5, pp. 510-524, 2009.

[15] P. Maier, "Spatial Geometry and Spatial Ability - How to Make Solid Geometry Solid?," Proc. Annu. Conf. Didact. Math., vol. 3, no. 1, pp. 69-81, 1996.

[16] Á. Bosnyák and R. Nagy-Kondor, "The spatial ability and spatial geometrical knowledge of university students majored in mathematics.," Acta Didact. Univ. Comenianae. Math., no. 8, pp. 1-25, 2008.

[17] P. Ivars, C. Fernández, S. Llinares, and B. H. Choy, "Enhancing Noticing: Using a Hypothetical Learning Trajectory to Improve Pre-service Primary Teachers' Professional Discourse,” Eurasia J. Math. Sci. Technol. Educ., vol. 14, no. 11, 2018.

[18] J. Yingprayoon, "Teaching Mathematics using Augmented Reality," Proc. 20th Asian Technol. Conf. Math., vol. 20, pp. 384-391, 2015.

[19] M. Dunleavy, "Design Principles for Augmented Reality Learning," TechTrends Link. Res. Pract. to Improv. Learn., vol. 58, no. 1, pp. 28-34, 2014.

[20] M. E. C. Santos, A. Chen, T. Taketomi, G. Yamamoto, J. Miyazaki, and H. Kato, "Augmented Reality Learning Experiences: Survey of Prototype Design and Evaluation,” IEEE Trans. Learn. Technol., vol. 7, no. 1 , pp. 38-56, 2014.

[21] M. Dunleavy and C. Dede, “Augmented Reality Teaching and Learning," in Handbook of Research on Educational Communications and Technology, 2013, $\quad$ pp. 